\title{
DE UMA LAICIDADE DE INCOMPETÊNCIA A UMA LAICIDADE DE INTELIGÊNCIA: O CASO DO ENSINO RELIGIOSO NA ESCOLA PÚBLICA
}

\author{
FROM A KIND OF LAICISM BASED ON INCOMPETENCE \\ TO A LAICISM BASED ON INTELIGENCE: \\ THE CASE OF RELIGIOUS TEACHING IN PUBLIC SCHOOLS
}

José ANTONIO CORREA LAges ${ }^{(*)}$

\begin{abstract}
RESUMO
Neste artigo analisa-se o Ensino Religioso na escola pública, contextualizado na realidade brasileira, marcada por grande pluralidade e diversidade cultural e religiosa. Nosso ponto de partida será o novo conceito de laicidade de conhecimento, um novo marco nas relações entre sujeitos, confissões religiosas e o Estado. Neste contexto, destacaremos o modelo de Ensino Religioso que busca realizar a transposição didática da (s) Ciência (s) da Religião para a escola. Este modelo assume um papel fundamental para a afirmação do respeito para com o outro, principalmente frente ao crescimento dos mais diversos fundamentalismos do nosso tempo e dos mitos que povoam a nossa sociedade capitalista. Ele poderá mostrar que a religião é o mais despercebido instrumento de sustentação (teórica e prática) de diversas formas de dominação, mas também pode ser uma referência para as resistências locais a essas na luta pela libertação em várias situações. A educação para a solidariedade se compromete com esta noção de alteridade. Sem isso, não é possível passar para a solidariedade como um valor ético, reconhecendo-se no outro sua própria dignidade humana. Neste sentido, veremos que este modelo de Ensino Religioso cumpre um papel fundamental.
\end{abstract}

Palavras-chave: Laicidade. Ensino do religioso. Cultura. Alteridade. Solidariedade.

\begin{abstract}
This article aims at analyzing Religious Teaching in Public Schools within the Brazilian context defined by great cultural and religious diversity. The starting point of the text will be the new concept of knowledge laicism, a new framework for relationships between subjects, religious confessions and the State. In this context, the model of Religious Teaching that aims at the didactic transposition of Religious Science to school will be outlaid. This model assumes a key role in the affirmation of respect for the other, especially on face of the growth of various contemporary fundamentalisms and myths that populate our capitalist society. It shows that religion is the most subtle support mechanism (theoretical and Empirical) to the various forms of domination, but it can also be a reference for local resistance to those people struggling for liberation in various situations. Education for solidarity is committed to this notion of otherness. Without it, it is not possible to ascertain solidarity as an ethical value, acknowledging oneself in the other its own human dignity. In this sense, we will see that this model of Religious Teaching plays a key role.
\end{abstract}

KEYWORDS: Laicit. Religious studies teaching, Culture. Othernes. Solidarity.

${ }^{(*)}$ Mestre em História pela Universidade Estadual Paulista - UNESP. Doutorando em Ciências da Religião pela Universidade Metodista de São Paulo - UMESP. E-mail: professorlages@gmail.com . 


\section{INTRODUÇÃO}

O caso do Ensino Religioso na escola pública deve ser visto sob a nova ótica de um Estado laico e mediador nas sociedades contemporâneas, inclusive no Brasil. Verificaremos, de saída, que este tema é de extrema complexidade, envolvendo uma série de variantes para uma abordagem equilibrada. Não há como trabalhar essa questão desconsiderando as conquistas republicanas do Estado laico, sobretudo a liberdade religiosa, bem como o reconhecimento de uma afirmação cada vez mais decisiva da pluralidade religiosa no Brasil. Situaremos os embates políticos sobre o tema, mas principalmente a discussão acadêmica sobre ele.

Na primeira parte, iniciaremos com a discussão sobre a emergência de um Estado laico, mas mediador, a partir da construção histórica de um novo conceito de laicidade de conhecimento, um novo marco nas relações entre os sujeitos, as confissões religiosas e o Estado. Para isso, tomaremos como referencial teórico as idéias da socióloga Danièle Hervieu-Léger, imprescindíveis para a compreensão da possibilidade e até da necessidade do Ensino Religioso em uma sociedade secularizada.

$\mathrm{Na}$ segunda parte, começaremos por observar a existência de projetos bastante díspares de Ensino Religioso que vêm sendo colocados em prática por alguns sistemas estaduais e municipais de ensino no Brasil, com toda a controvérsia levantada nos meios jurídicos e com forte repercussão na mídia. Tomaremos como ponto de partida a discussão lingüística promovida por Pierre Bourdieu na busca da percepção de toda uma carga de poder simbólico em torno da própria expressão Ensino Religioso.

Destacaremos, na terceira e última parte, o modelo de Ensino Religioso não confessional e não proselitista, como aplicação da(s) Ciência(s) da Religião para os currículos escolares, entendendo ser esta uma possibilidade ainda bastante incipiente, no entanto mais condizente com uma visão de Estado laico e mediador e com uma sociedade secularizada como a nossa. O que está em jogo é o lugar do Ensino Religioso no âmbito público. Qual é a utilidade do Ensino Religioso para uma sociedade como a nossa? Essa parece ser a questão que deve ser enfrentada de frente. Para esta discussão, buscaremos como referenciais autores como Frank Usarski, Faustino Teixeira, Danilo R. Streck, Luiz Felipe Pondé, Jorg Rieger, Edgar Morin, René Girard e Jung Mo Sung.

Veremos que aquele modelo poderá assumir um papel fundamental para o reconhecimento da diversidade e da afirmação do respeito para com o outro, principalmente frente ao crescimento dos mais diversos fundamentalismos do 
nosso tempo e dos mitos que povoam a nossa sociedade capitalista. Além disso, pretendemos demonstrar que o estudo dos conhecimentos religiosos nos ambientes escolares é fundamental, não só porque a religião pode ser o mais despercebido instrumento de sustentação (teórica e prática) das mais diversas formas de dominação, inclusive, historicamente, do colonialismo. Mas principalmente porque ela é uma referência, ao mesmo tempo, para as resistências locais a estas e a outras diversas formas de dominação.

Nesse sentido, a escolarização dos saberes religiosos tem uma grande contribuição a dar também em uma educação comprometida com valores éticos e com a formação da cidadania das crianças e adolescentes. Na busca de um sentido último para a vida a educação tem um papel a cumprir quando se compromete claramente com a noção de alteridade, da relação com o outro. Sem isso, não é possível passar para a solidariedade como um valor ético, um movimento de ir ao encontro do outro, reconhecendo-se no outro sua própria dignidade humana. Conhecer as religiões e a experiência religiosa, aproximar-se da sua força espiritual é uma estratégia pedagógica fundamental, se quisermos uma educação para a solidariedade.

\section{A EMERGÊNCIA DE UM ESTADO LAICO E MEDIADOR}

Temos atualmente o pluralismo e a diversidade como valores de convivência com importantes conseqüências para a vida da humanidade. Neste novo e alvissareiro marco, é necessário reformular o conceito de laicidade que se impõe cada vez mais como uma nova forma de organizar a convivência e as relações entre os grupos religiosos e o Estado. O objetivo final dessa nova forma não é alcançar a supremacia de um sobre o outro, mas sim reconhecer a dignidade e a autonomia das pessoas e garantir o exercício de sua liberdade. O foco agora são as pessoas e não mais o Estado nem as Igrejas.

Hervieu-Léger (2008) faz interessante relação entre modernidade e reconfiguração do campo religioso para poder discutir a questão da laicidade que deve ser colocada em novos termos. Ela afirma que as crises sócio-culturais costumam acompanhar os desequilíbrios econômicos ou até antecipá-los, como ocorreu em 1968 e agora, na Europa, sacudida pela crise financeira internacional. Nesses períodos, os sistemas religiosos tradicionais readquirem em formas novas um grande poder de atração sobre os indivíduos e sobre a sociedade.

Ela não está falando de retorno do religioso ou de revanche divina, mas são fenômenos que, pelo contrário, trazem à luz o caráter paradoxal da modernidade do ponto de vista da crença. De um lado, a perda do controle das crenças e práticas 
pelas instituições religiosas; por outro, a própria modernidade secularizada, geradora de utopia e opacidade, cria condições favoráveis à expansão da crença. Hervieu-Léger afirma que

[...] secularização não é, pois, a perda da religião, mas o conjunto dos processos de reconfiguração das crenças que se produzem em uma sociedade onde o motor é a não satisfação das expectativas que ela suscita, e onde a condição cotidiana é a incerteza ligada à busca interminável de meios para satisfazê-las. (HERVIEULÉGER, 2008, p. 41)

É necessário, então, passarmos de uma laicidade de incompetência para uma laicidade do conhecimento. Como afirma Régis Debray: "a laicidade pública não é tudo a Cesar [...] mas sim a consciência e a liberdade dos homens chamados a viver juntos, apesar de tudo o que os separa, os opõe e os divide”. (DEBray apud DA CoSTA, 2006, p. 5).

Hervieu-Léger (2008) afirma que o Estado deve proteger as pessoas na sua relação com os grupos religiosos, mas deve também proteger o direito da livre escolha das pessoas e das associações de se organizarem livremente. Comum em muitos países, essa mútua legitimação da ação social do Estado e dos grupos religiosos constitui um elemento novo no contexto francês e, por extensão, na de vários outros países também. Não é um processo tranquilo, principalmente quando se colocam questões relacionadas aos direitos reprodutivos e à homossexualidade. Mas já existe grande contribuição comum para a prática cidadã que substituiu o enfrentamento de posições irreconciliáveis do passado.

Não podemos deixar de observar que as relações entre a República laica e as religiões podem se deslocar, e mesmo passar de um regime de neutralidade/desconhecimento relativamente pacífico que podemos chamar de laicidade de incompetência ou de ignorância ao de uma cooperação razoável em matéria de produção de referências éticas, de preservação da memória e da construção de vínculo social, a que podemos chamar de laicidade do conhecimento, de inteligência e de compreensão.

\section{ESTADO LAICO E ENSINO RELIGIOSO: OUTRAS PERSPECTIVAS}

A questão do Ensino Religioso na escola pública tem suscitado amplo debate na sociedade brasileira, desde a Constituição de 1988 e sua regulamentação pela Lei de Diretrizes e Bases da Educação Nacional (LDBEN, Lei no 9394/96 modificada em seguida pela Lei n. ${ }^{\circ}$ 9.475/97). Podemos sintetizar este debate que envolve organismos do Estado, gestores e órgãos da área de educação, confissões religiosas e setores acadêmicos, estabelecendo três grandes vertentes para esta discussão: $1^{\mathrm{a}}$ ) os que não admitem, em hipótese alguma, o Ensino 
Religioso na escola pública, escudados na defesa da laicidade do Estado; $2^{\text {a) }}$ os que advogam o Ensino religioso claramente confessional, utilizando as brechas originadas das contradições da própria lei [especialmente uma alteração feita na Lei das Diretrizes e Bases da Educação Nacional (LDBEN, Lei 9475/97): um órgão colegiado integrado pelas confissões deverá estabelecer os conteúdos a serem ministrados] e $3^{\text {a }}$ ) os que admitem o Ensino Religioso na escola pública como área de conhecimento no currículo escolar, privilegiando a escolarização e não os interesses das confissões religiosas e os interesses políticos, como uma aplicação da(s) Ciência(s) da Religião.

Não existe hoje no Brasil um consenso em torno da questão do Ensino Religioso nas escolas públicas. É um tema que envolve uma série de variantes. Não há como trabalhar esta questão desconsiderando as conquistas republicanas do Estado laico, sobretudo a liberdade religiosa, bem como o reconhecimento de uma afirmação cada vez mais decisiva da pluralidade e diversidade religiosas no país. Nessas últimas décadas, o Brasil vem passando por importantes mudanças no campo religioso e isso recondiciona a visão da laicidade como também o próprio tratamento da questão do Ensino Religioso entre nós.

Há uma questão de fundo que precisa ser esclarecida logo de início. O que se acostumou até hoje entender por Ensino Religioso? Vamos recorrer a Pierre Bourdieu e à sua obra Economia das trocas lingüísticas ${ }^{1}$ para começar a entender esta questão.

Bourdieu busca desvelar o poder distintivo das palavras e compreendê-las dentro de uma perspectiva da análise de uma conjuntura social repleta de tensões. A ideia de que "toda ação é uma conjuntura" tem por objetivo empreender uma crítica a uma determinada análise linguística que busca na singularidade da própria língua, no seu funcionamento interno, as explicações para os diferentes posicionamentos de emissores e receptores num dado momento de fala. Embora seja legítimo tratar as relações sociais como interações simbólicas, isto é, como relações de comunicação que implicam o conhecimento e o reconhecimento, "não se deve esquecer que as trocas linguísticas - relações de comunicação por excelência - são também relações de poder simbólico [...]”. (BouRdIEU, 1996, p. 24).

Bourdieu fundamenta sua argumentação, primeiramente desconstruindo a ideia de uma língua legítima dada como natural e comumente usufruída por um

${ }^{1} \mathrm{O}$ artigo $O$ poder das palavras: descrever e prescrever, de Ana Claudia Mielki, publicado na Revista Rumores, edição 6, volume 1, set/dez de 2009, no site <http://www.usp.br/rumores/> aprofunda de forma muito interessante esta questão do poder simbólico das palavras e expressões nas diversas situações marcada por tensões políticas na sociedade. 
grupo de sujeitos falantes. Segundo ele, aquela visão de que "não é o espaço que define a língua, mas a língua que define seu espaço [...] oculta o processo propriamente político" (BouRdiEU, 1996, p. 31) que leva o grupo de falantes a aceitarem tal língua como sendo a oficial. A língua oficial é apenas tornada legítima em consonância com as condições socioeconômicas que permitem tal legitimação - apenas em virtude de um mercado linguístico.

A tese levantada por Bourdieu de que as palavras descrevem e prescrevem, de que têm capacidade de "produzir ou reforçar simbolicamente a tendência sistemática para privilegiar certos aspectos do real e ignorar outros" (BOURDIEU, 1996, p.125), constitui-se como um importante instrumento teórico para aqueles interessados em investigar o poder simbólico, constituído pelas palavras (a eficácia simbólica da linguagem na construção da realidade). Não as palavras em sua aparente neutralidade, mas as palavras dispostas em luta - na luta permanente pelo estabelecimento do consenso sobre o sentido, pelo estabelecimento de uma visão do mundo social.

Essa discussão sobre o poder das palavras é importante quando se inicia uma análise sobre o Ensino Religioso no Brasil. Estas são palavras carregadas de sentido, como diz Bourdieu (1980), inseridas num contexto social repleto de tensões. São palavras que trazem um forte poder simbólico, elas não são neutras. São palavras em luta. Em torno do Ensino Religioso encontramos um histórico de embates ideológicos desde a Escola Nova, opiniões cultural e politicamente divergentes no seio da sociedade nacional e interesses fortemente ligados à concepção de Estado e aos interesses das confissões religiosas. Ao ponto de Ensino Religioso ser percebido natural e espontaneamente pela maioria das pessoas como ensino de doutrina religiosa nas escolas. E no centro desse conjunto de interesses, concepções e tensões, nós podemos encontrar a questão da laicidade, expressão esta também fortemente carregada de sentido.

O debate do Ensino Religioso na escola pública frente à laicidade do Estado permanece no Brasil preso a um forte viés jurídico-político. Aqueles que são contrários a qualquer forma de Ensino Religioso na escola pública justificam a sua posição na defesa do caráter laico do Estado previsto na Constituição (art. 19) e em vários de seus dispositivos relacionados à dignidade da pessoa humana (art. $1^{\mathrm{o}}, 3^{\mathrm{o}}$ e $4^{\mathrm{o}}$ ), à igualdade de todos perante a lei (art. $5^{\circ}$ ) e ao dever da família, da sociedade e do Estado em relação às crianças e adolescentes (art. 227). A preocupação é com a liberdade de consciência, de crença e de culto. (FischmANN, 2008).

Assim, a discussão em certos meios permanece no âmbito legal, constitucional, envolvendo interesses do Estado e das confessionalidades, principalmente a hegemônica 
em nosso país, e não abrange a contextualização do Ensino Religioso na escola pública no contexto educacional e pedagógico, dentro de um processo de escolarização voltado para os estudos de cultura e para a cidadania. Mas ressalta-se que esta é apenas uma possibilidade colocada e precisa de uma ampla discussão que propomos aqui apenas iniciar. Nossa hipótese é que é possível o Ensino Religioso na escola pública, como área de conhecimento curricular comprometido com a formação geral do educando, inclusive com a construção de valores para a sua vida, sem caráter confessional e sem objetivos proselitistas, com respeito à laicidade do Estado, à diversidade cultural e à pluralidade religiosa da sociedade brasileira.

Admitimos que é possível o estudo dos conhecimentos religiosos, e mais que isso, o estudo daquilo em que se baseiam todas as religiões - ou seja a dimensão transcendental da vida humana: o Sagrado - como área de conhecimento configurada num componente curricular (como prevê a legislação) no contexto do Estado laico. Os contrários a esta alternativa partem de um conceito fechado de laicidade, tão somente entendida como separação entre Estado e Igreja, sem levar em conta a construção social/histórica deste conceito refletindo as realidades próprias de cada sociedade. Percebe-se que quase sempre se apegam a um conceito militante, geralmente inspirado no caso francês, que Demétrio Velasco (2006, p. 16) chamou de laicidade de exclusão por substituição ${ }^{2}$, mas que na própria França encontra-se hoje em plena revisão.

Se a religião é uma das falas ausentes (ou silenciadas) no discurso acadêmico, na escola também o é, sem nunca ter sido. É de reconhecimento geral que todos os envolvidos no processo docente transmitem, conscientemente ou não, ideias, valores e princípios, inclusive de cunho religioso ou contra qualquer religião, aos educandos em todas as disciplinas. Afinal, se a ciência não é neutra, a educação também não o é.

Fora da escola, com exceção de algumas confessionalidades, inclusive a Católica, ninguém assume o Ensino Religioso na escola pública, muito menos o Estado Federal e boa parte da Academia. Ninguém de fato se sente autorizado a assumi-lo. Prevalece o silêncio ou o "lavar as mãos", apesar de sua previsão legal, com todas as contradições, que podem ser positivas ou não, decorrentes de uma legislação que deixa para os sistemas de ensino a definição de objetivos, conteúdos, formação do professor, decisão sobre avaliação e muitas outras questões pertinentes.

\footnotetext{
${ }^{2}$ Essa forma se refere a um laicismo agressivo e militante que busca eliminar a presença da religião na vida social em nome da liberdade, paralelo ao paradigma da secularização entendido como a eliminação da religião da vida pública.
} 
Acreditamos que o convencimento sobre a conveniência do Ensino Religioso na escola pública se dá, pois, no âmbito mais amplo e profundo de duas grandes questões. A primeira, solidamente cristalizada, é a da laicidade do ensino que exclui os conteúdos religiosos como ameaça aos princípios fundantes do Estado Moderno. A segunda, ainda fragilmente constituída, é a fundamentação epistemológica desse ensino como área de conhecimento. O convencimento sobre a primeira questão, sem levar em conta a segunda, acaba por abrir espaço para as confissões religiosas assumirem a condução do Ensino Religioso, uma vez que são detentoras, segundo a própria concepção dada pelo Estado, dos conhecimentos religiosos (e até a LDBEN consagra esta concepção quando passa para as confissões religiosas a responsabilidade de definição de conteúdos).

Todos os esforços historicamente realizados no sentido de se construir uma prática coerente dessa disciplina gravitou sempre em torno da questão da confessionalidade religiosa e da laicidade do Estado. É possível hoje pensar um modelo que supere este impasse em nome da autonomia dos estudos de religião e da própria educação?

A rigor, como já foi dito, o convencimento a ser feito é, portanto, fundamentalmente de ordem epistemológica, ou seja, a demonstração do estudo da religião como área de conhecimento que pode gozar de autonomia teórica e metodológica, sendo capaz de subsidiar práticas de ensino dentro dos sistemas de ensino laicos, sem nenhum prejuízo de suas laicidades, ao contrário, a favor delas. 3

Mas talvez não baste uma justificativa epistemológica para o Ensino Religioso na escola pública. Há também de se destacar sua função teleológica. Ensino Religioso na escola pública para quê? Que papel teria ele no currículo escolar? A própria escola tem uma função de formação dos seus educandos? Hoje, já existe uma concordância geral, entre educadores, acadêmicos, famílias, igrejas, Estado, de que sim! A educação formal escolar tem, assim, qual função? No contexto desta resposta é que precisamos situar o Ensino Religioso. É o que faremos na terceira parte deste trabalho.

Toda ciência é ensinada nas escolas com finalidades pedagógicas e possui crenças embutidas em seus programas. A educação não pode ser uma simples reprodução de princípios e métodos neutros, mas, sim, de valores a serem assimilados pelos educandos. A educação do intelecto e da vontade funda-se numa teleologia: que tipo de pessoa e de sociedade se deve e se quer construir?

\footnotetext{
3 De fato, o estudo científico das religiões é tão laico quanto qualquer outro inscrito na espera das ciências que são ensinadas nas escolas (o que não significa que todo ensino não traga em seus objetivos a formação de valores nos educandos).
} 
E este é um objetivo de toda a educação expresso no projeto político-pedagógico da escola. A composição curricular é o meio a ser percorrido para tal finalidade.

Dentro desse quadro geral da educação para a formação de valores e de cidadania, o que está em jogo é o lugar do Ensino Religioso no âmbito público. Qual é o papel do Ensino Religioso para uma sociedade contemporânea, laica e secularizada? Essa parece ser a questão que está por trás de toda a discussão em torno da Constituição, da LDBEN e da própria laicidade do Estado.

A escola ensina o conhecimento acumulado pela humanidade no que diz respeito a todas as áreas da natureza, da técnica e das humanidades, incluindo as mais diversas expressões da cultura, como as linguagens, as artes, mas não pode colocar a religião como objeto de estudo? Mesmo com o reconhecimento da religião como um fenômeno que, em vez de seu desaparecimento previsto desde os defensores da "morte de Deus", hoje, pelo contrário, ocupa um lugar público cada vez mais aceito, principalmente na América Latina, África e Ásia?

A questão da laicidade permanece como o pano de fundo de toda a controvérsia. Por isso, aprofundar nessa questão é crucial. Acreditamos que a discussão do Estado laico frente ao Ensino Religioso na escola pública é a porta de entrada do problema. E ela vem sendo feita por alguns círculos acadêmicos em torno de Sueli Carneiro e Anna Cândida da Cunha Ferraz, da USP, Débora Diniz, da UNB, Roseli Fischmann, da UMESP, Daniel Sarmento, da UERJ, Luiz Antônio Cunha, da UFF e de muitos outros. Mas quando ela avança nas críticas de certas experiências desenvolvidas em alguns sistemas estaduais e municipais de ensino, sua crítica enfoca particularmente o que há de notório e flagrante descumprimento da lei, no caso os estados do Rio de Janeiro e Bahia, por exemplo, com o seu projeto de ensino religioso confessional. Essas críticas passam ao largo de outras experiências como a do Fórum Nacional Permanente do Ensino Religioso (FONAPER) e a dos estados do sul, com perspectivas bem diferentes. $4 \mathrm{Ou}$ se essas experiências são discutidas, são mal compreendidas e/ou mal explicitadas. Na verdade, são silenciadas.

Não há como desconhecer o fenômeno religioso na sociedade, os enormes deslocamentos internos desse campo, inclusive no Brasil, sua presença e

\footnotetext{
4 Segundo a tese de Marislei Sousa Espíndula Brasileiro, apresentada em 2010 ao Programa de PósGraduação em Ciências da Religião na PUC-GO, em Goiânia, existe no Brasil uma enorme diversidade de modelos de Ensino Religioso na escola pública. Ela aponta como confessional o modelo adotado pelos estados do Acre, Bahia, Ceará, Espírito Santo e Rio de Janeiro. O estado de São Paulo aplica na disciplina de Ensino Religioso conteúdos de História das Religiões. O estado de Goiás adota um modelo transconfessional. Já os estados do Paraná e Rio Grande do Sul são os únicos que adotam um modelo supraconfessional, a partir da aplicação didática das Ciências da Religião. Segundo a pesquisadora, os demais estados adotam um modelo que, no conjunto, poderia ser chamado de confessional-ecumênico. Ela aponta diversas nuances entre estes modelos, impedindo uma classificação muito rigorosa, o que leva, inclusive, outros pesquisadores que fizeram levantamentos semelhantes a conclusões um pouco diferentes.
} 
intervenção cada vez maior no espaço público, independente de qualquer regulamentação legal. Isso interessa às ciências sociais e, de modo especial, às ciências da religião5. Há de interessar também ao aprendizado escolar, inclusive das escolas públicas, não somente no sentido de informar sobre aquele fenômeno, mas de ter consciência de seu papel na sociedade, de ter opinião sobre ele, de se posicionar como cidadão crítico e consciente. O Estado laico, portanto, tem algo a dizer sobre a religião na escola pública.

\section{3 “ENSINO DO RELIGIOSO” EM VEZ DE “ENSINO RELIGIOSO”. PARA QUÊ?}

No início da terceira parte deste trabalho, podemos lembrar aqui uma discussão muito comum nos meios acadêmicos em torno do estudo das religiões, mas que nós podemos de certa forma levar também para os meios escolares. Trata-se da proposta de alguns estudiosos da necessidade de certo “ateísmo metodológico" para se garantir a neutralidade do estudo da religião do ponto de vista científico, afastando-se qualquer tipo de contágio/contaminação religiosa, em paralelo com o argumento de que a religião deve estar ausente da escola pública, pois, também pelas mesmas razões, a religião não caberia num ambiente de estudo de disciplinas científicas. Diante do "horror do invisível", esse procedimento metodológico acaba justificando não uma perspectiva de neutralidade objetiva, mas de "militância anti-religiosa”, como mostra Luiz Felipe Pondé:

O 'ateísmo metodológico' tem pavor de adentrar uma região de experiência interna humana que simplesmente desconhece, ainda que se diga especialista nela. Não seria a não experiência do tato religioso um caso particularmente e culturalmente recente de uma 'miséria' da cognição? (PONDÉ, 2001, p.57).

Na visão de Pondé, o argumento que sustentaria tal procedimento metodológico, ou seja, a exclusão apriorística da substância religiosa seria

[...] uma postura essencialmente anti-religiosa na qual seria traída uma visão de experiência e vida religiosa como algo necessariamente danoso para a vivência racional e cognitivamente emancipada do ser humano. (PONDÉ, 2001, p. 54-55).

Não é preciso lembrar que esta visão criticada por Pondé (2001) e Teixeira (2001) pode ser encontrada não apenas nos meios acadêmicos, mas em vários outros segmentos da sociedade. Em alguns partidos de esquerda ou em tendências deles, em alguns movimentos sociais e sindicatos, podemos

\footnotetext{
5 Para um maior aprofundamento sobre o espaço acadêmico da(s) Ciência(s) da Religião, indicamos as seguintes obras: Constituintes da Ciência da Religião, de Frank Usarski, editada pelas Paulinas em 2006, e A(s) Ciência(s) da Religião no Brasil: afirmação de uma área acadêmica, coletânea de artigos organizada por Faustino Teixeira, editada também pelas Paulinas em 2001.
} 
encontrar uma postura flagrantemente impermeável a qualquer crença religiosa e principalmente à sua presença no âmbito público, como nas escolas. Talvez seja um resquício de uma tradição marxista ortodoxa escudada no entendimento tradicional, mas hoje já bastante questionável da religião como "ópio do povo".

Entendemos que pesquisadores sem-religião, não necessariamente ateus, mas que nunca tiveram experiências religiosas, podem escrever sobre as religiões e sobre o Ensino Religioso. O interessante é que em vários âmbitos políticos e acadêmicos reconhecidamente distantes da questão religiosa, seja pela sua postura filosoficamente ateia, seja pela sua clara origem ideológica marxista, começa-se a esboçar outra visão sobre o Ensino Religioso no âmbito público. Ninguém menos que Régis Debray, por exemplo, onze anos atrás, nos trazia uma posição bastante surpreendente. Interessante relatório seu a pedido do Ministério da Educação da França propôs o Ensino "do religioso" (l'enseignement du religieux) em vez do Ensino Religioso na escola pública, buscando uma aproximação "descritiva, factual e nocional” das religiões em sua pluralidade, sem privilégios e exclusividades. O desafio apontado por Debray se refere à "incultura religiosa" dos estudantes das escolas públicas, decorrente principalmente da ruptura das identidades religiosas herdadas, o que dificulta, em sua opinião, a formação geral dos estudantes. ${ }^{6}$

Sua proposta se aproxima do projeto do sistema estadual de ensino do estado de São Paulo que nunca foi plenamente executado. O seu encaminhamento não se daria através de uma disciplina específica, mas através da ampliação do âmbito das disciplinas já existentes, como Filosofia, História, Geografia, e Línguas. Os professores receberiam uma preparação específica para ampliar a sua competência no manejo dos assuntos relacionados à religião.

A inserção do estudo 'do religioso' não significaria romper com a tradição da laicidade francesa, mas passar de 'uma laicidade de incompetência' (o religioso, por construção, não nos interessa) a uma 'laicidade de inteligência' (é nosso dever compreendê-lo). (TEIXEIRA, 2006, p. 72-73).

Faustino Teixeira afirma que não há como excluir a possibilidade do acesso à reflexão apropriada sobre o religioso na escola pública, levando-se em conta a importância do fator religião na sociedade brasileira e de sua relevância para a

\footnotetext{
6 Sempre existiram crises de transmissão que hoje assumem, no entanto, uma mudança profunda de natureza. Hoje elas são lacunas que representam verdadeiras rupturas culturais que atingem a identidade social, a relação com o mundo e a capacidade de comunicação dos indivíduos. Observa-se um remanejamento global das referências coletivas, rupturas da memória (as sociedades atuais são cada vez menos sociedades de memória e cada vez mais sociedades do imediatez), reorganização de valores que questionam os próprios fundamentos dos laços sociais. E a religião, por mais que não seja percebida, está no centro de todo este processo que é social, religioso, mas, sobretudo, existencial.
} 
compreensão da nossa própria cultura. "E as ciências da religião constituem um canal importante para possibilitar este exercício reflexivo: de aperfeiçoamento da compreensão do religioso como 'objeto de cultura', ou fenômeno de cultura”. (2006, p.73).

As tradições religiosas são portadoras de um "rico patrimônio espiritual" que para Teixeira justificam o seu estudo no âmbito escolar como área de conhecimento, mas, além disso, também um exercício de maior aproximação existencial, um contato mais estreito com elas. Teixeira avança ainda mais na concepção do ensino “do religioso” em relação a Régis Debray, afirmando:

E para isso, faz-se necessário também o aperfeiçoamento do 'tato religioso', que favorece a superação de uma certa mentalidade que resiste em adentrar-se em esferas particulares da experiência humana, limitando-se a reduzir o engajamento vivido pelo outro a uma mera 'rapsódia de observações exteriores e frias'. Não há como compreender o contexto histórico das religiões, desconectando-o da "espiritualidade" que o anima. (TEIXEIRA, 2006, p. 75).

No mesmo livro em que se encontra o artigo de Teixeira acima citado, organizado por Luzia Sena (2006), há um interessante artigo de Frank Usarski intitulado "Ciência da Religião: uma disciplina referencial", no qual o autor estuda o desenvolvimento do Ensino Religioso alternativo ao tradicional na Alemanha, tirando hipóteses sobre possíveis aplicações no Brasil.

Atualmente as legislações de todos os 16 estados federais alemães reconhecem a importância de uma alternativa ao Ensino Religioso tradicional (confessional, luterano ou católico), sob as mais diversas nomenclaturas. Para Usarski, é possível perceber naqueles diversos programas três áreas em que a Ciência da Religião deve desempenhar um papel como "disciplina de referência":

Primeiro, um conhecimento pelo menos sobre as principais religiões do mundo e fenômenos tipicamente associados a elas. Segundo, o objetivo de gerar e aprofundar no aluno a atitude da tolerância enquanto integrante de uma sociedade multirreligiosa e pluricultural. E terceiro, o propósito de capacitar os participantes do curso a associar suas próprias preferências ideológicas a quadros filosóficos cujo caráter sistemático questiona ecletismos subjetivos ingênuos e a combinação ingênua de elementos de origem variáveis muitas vezes logicamente incompatíveis. (USARSKI, 2006, p. 57-58).

Danilo R. Streck (1998), partindo de um conceito aberto de ecumenismo, numa visão mais cultural que apenas religiosa, defende a escolarização do conhecimento do fenômeno religioso como instrumento fundamental para o reconhecimento da diversidade e de afirmação do respeito para com o outro. Este respeito, mais que tolerância seria, na verdade, a aceitação do diferente, 
[...] na esperança de contribuir para uma educação que ajude as pessoas a sentirem o mundo como sua casa (oikos) comum, em constante processo de construção para que todos e todas nela tenham lugar. (STRECK, 1998, p.39).

A partir desta primeira proposição, Streck avança em seus desdobramentos para concluir na necessidade do Ensino Religioso na escola pública como imprescindível para a formação de crianças e adolescentes, principalmente frente ao crescimento dos mais diversos fundamentalismos, religiosos ou não. A esse respeito Teixeira acrescenta que ele é também necessário para o "aperfeiçoamento do olhar e da escuta do mundo e da alteridade e o respeito à sua dignidade, a percepção da riqueza e do valor de um mundo plural e diversificado e a recuperação da força espiritual das religiões.” (TEIXEIRA, 2006, p. 75-76).

Streck (1998) apresenta uma posição interessante, mais situada no campo propriamente da Teologia. Para ele o Ensino Religioso pode ser confessional, sem ser proselitista, mas comprometido com o diálogo religioso e com o ecumenismo. Para ele, pode-se aprender a ser ecumênico - a aprendizagem ecumênica é um processo que tem de ser construído inclusive a partir da escola, já que esta não é, por natureza, um espaço ecumênico. Ele defende um Ensino Religioso ecumênico que pode ser relevante para ajudar os educandos a lidar com as questões existenciais, as questões de fé:

[...] este tipo de ecumenismo pode interessar a um Estado radicalmente democrático, a instituições religiosas abertas a questionamentos e interessadas mais no crescimento da fé do que em sua preservação enquanto instituições e a escolas dispostas a se envolver de uma maneira mais profunda com o drama do ser ou se fazer humano. (STRECK, 1998, p. 47).

Recorreremos agora a outro referencial que até o momento ainda não foi colocado para justificar o Ensino Religioso na escola pública: os estudos subalternos ou pós-coloniais. Jorg Rieger (2008), afirma que o estudo da religião é fundamental, não só porque ela foi a primeira sustentação (teórica e prática) das mais diversas formas de dominação econômica, social, cultural e política do colonialismo moderno, mas principalmente porque ela é uma referência, ao mesmo tempo, para as resistências locais a estas e a outras formas de dominação contemporâneas relacionadas a questões de raça, gênero, opções sexuais, religiosas etc. Se as culturas locais são fundamentais para se pensar e praticar um outro mundo possível, não é salutar pensar um projeto pedagógico sem considerar o imaginário religioso de todos os atores envolvidos com o projeto político-pedagógico da escola pública.

Rieger (2008) nos lembra que o impulso inicial para a opção preferencial pelos pobres da Teologia da Libertação foi teológico. Mas, em seguida, ele coloca 
duas questões que nos interessam mais de perto: que diferença fazem Teologia e Religião a este respeito? Não seria qualquer referência sincera às margens ou ao subalterno suficiente para resistir ao colonialismo/neocolonialismo e levar os estudos pós-coloniais ao próximo passo? E nós acrescentaríamos: indo além da Teologia da Libertação, contextualizada como sabemos na América Latina, que importância libertadora teria o estudo da(s) religião(ões) não apenas para o homem da América Latina, mas para o homem no contexto de qualquer situação existencial, em qualquer lugar do mundo que esteja à margem ou nas fronteiras, para continuarmos utilizando uma terminologia própria dos estudos subalternos?

Para ele existem pelo menos duas respostas a estas perguntas. Uma, da perspectiva do estudo da religião, mais amplamente concebida e que diz respeito ao nosso tema, e a outra, mais especificamente desde a perspectiva da teologia.

$\mathrm{Na}$ perspectiva do estudo do religioso, sabemos que todos os impérios coloniais modernos foram justificados religiosamente. Por este motivo o estudo crítico da religião é crucial para investigações pós-coloniais. E mais: nessa história o cristianismo precisa ser especialmente escrutinado. Rieger (2008) afirma que Walter Mignolo (2003) foi muito feliz quando apontou que o cristianismo se tornou o primeiro desenho global do sistema mundial moderno/colonial, depois da bem-sucedida expulsão dos judeus e árabes da Espanha e da conquista das Américas. Para Rieger:

Como tal, o cristianismo tornou-se uma base ideológica importante sobre a qual as estruturas coloniais de poder podiam ser construídas Uma religião que identificou Deus que está ao lado dos poderes coloniais, sejam eles os monarcas da Espanha e de Portugal, sejam os corpos governantes mais amplamente constituídos, sejam as tentativas dos Estados Unidos de "civilizar" a América Latina pós-colonial, deixou marcas para valer. Neste contexto, deixar de considerar o elemento religioso seria fechar os olhos para um dos motores do colonialismo. (RIEGER, 2008, p. 96).

Sabemos que desconsiderar o religioso leva-nos a perder não somente a oportunidade de retrabalhar uma parte importante da história colonial e póscolonial, como também nos conduz a perder um elemento importante da resistência que continua em tempos pós-coloniais e chega até a contemporaneidade. Em muitos casos, assuntos religiosos fornecem sementes de tal resistência.

Muitas pessoas nas margens de nosso atual império levantam questões religiosas e são motivadas por elas - um fato que em algum grau é reconhecido também nos Subaltern Studies Groups. Em muitos lugares - e podemos citar a África do Sul, a América Latina, certas regiões na Ásia e até mesmo os Estados Unidos -, comunidades de fé têm se envolvido em resistir a estruturas coloniais, conduzindo as suas vidas de modo alternativo. Rieger conclui que "enquanto a 
história do colonialismo olha o cristianismo mais de perto, a história da resistência exige um horizonte religioso muito mais amplo, que inclui interesse por outras religiões e diálogo inter-religioso”. (RIEGER, 2008, p. 101).

Também numa perspectiva de formação para a tomada de uma consciência e de uma atitude que Rieger chama de pós-colonial, o Ensino "do Religioso" na escola pública tem um papel a cumprir. Um papel de preparar os alunos, a partir do estudo da (s) religião (ões), para uma vida de resistência frente a toda onda de formas desumanizadoras da vida, típicas da civilização pós-moderna em que vivemos.

Sabemos que aceitar o diferente não é apenas tolerá-lo. Mas sabemos também que aceitar o diferente vai muito além de uma postura neutra e indiferente. Ela exige uma profunda relação de alteridade que nos leve a tomar a posição ativa de solidariedade. Resta saber, na linha de raciocínio que adotamos até aqui, se estudar os saberes religiosos na escola contribui para uma formação para a solidariedade. Acreditamos que sim. Resistir ás estruturas de dominação neocoloniais é uma postura que exigirá um compromisso de solidariedade com os dominados ou excluídos.

Já ouvimos falar muito que a escola deve preparar para a vida. Entendemos que preparar para a vida significa encontrar um sentido último para ela. A educação escolar deve se pautar pela busca deste sentido e isso supõe o discernimento entre os muitos mitos que povoam a sociedade contemporânea, alguns dos quais nos levam a uma postura de vida humanizadora e solidária, outros, de vida desumanizadora e egoísta.

Esse sentido último para a vida não pode prescindir da solidariedade como um imperativo ético, como um valor, um movimento de ir ao encontro do outro, reconhecendo-se no outro sua própria dignidade humana numa profunda relação de alteridade. Solidariedade com o próximo e com os excluídos e vítimas da lógica sacrificial da idolatria do mercado (GIRARD, 1990). A educação para a solidariedade seria o caminho para "reencantar a vida, ou seja, dar-lhe um sentido último, alcançar aquela situação em que se conclui que a vida vale a pena de ser vivida” (SuNG, 2002), independentemente de qualquer crença religiosa.

No contexto do projeto político-pedagógico da escola, todas as disciplinas estão comprometidas com este objetivo. No entanto, os saberes religiosos ocupam uma posição de excelência. A experiência religiosa faz parte do acontecimento humano, com os fatos e os sinais que a expressam e, por isso, tem grande importância para o conhecimento teórico e para a tomada de uma posição diante da vida. Ela tem muita contribuição a dar para uma educação para a solidariedade, na busca deste sentido último para a vida. 
Uma tarefa tão especial como esta precisa de uma disciplina específica que sistematize as contribuições feitas por outras e desenvolva temas e experiências que precisam de uma atenção especial.

Morin, falando da necessidade de uma ciência antropossocial religada, que concebesse a humanidade em sua unidade antropológica e em suas dimensões individuais e culturais, reconhece que essa religação ainda está fora do alcance das ciências e que por isso é importante que o ensino de cada uma delas fosse orientada para a condição humana. Isso inclui as ciências naturais, pois a condição humana é, ao mesmo tempo, físico-químico-biológico-antropológicosocial-simbólica. (SUNG, 2006, p. 41-42).

Edgar Morin (2000) afirma que os saberes sobre os mitos e as religiões seriam orientados para o destino mítico-religioso do ser humano. De fato, as religiões, mitos e ideologias devem ser considerados em sua ascendência sobre as mentes humanas, e não mais como 'superestruturas'. Morin chama essa disciplina ou ciência de noologia e afirma que ela está ainda por ser construída. Mas, diríamos nós, os trabalhos dessa área, que já existem, pelo menos no campo dos saberes religiosos, precisam ser mais conhecidos e desenvolvidos. De qualquer forma, uma nova ciência não submetida à totalitária racionalidade ocidental.

O estudo escolar dos saberes religiosos pode desde já resgatar o encanto por um sentido último da vida como quer Sung (2006). Para isso, aquele discernimento dos mitos que povoam o nosso tempo há de passar necessariamente pela dessacralização do mercado e pela crítica à idolatria sacrificial do capitalismo. Esta será a porta de entrada para se posicionar a favor de uma sociedade mais humana e solidária. Assim também será possível reconhecer-se o papel do estudo das religiões no âmbito escolar em uma sociedade marcada pela diversidade cultural, pluralidade religiosa e receptiva à laicidade do Estado.

\section{CONCLUSÕES}

O Supremo Tribunal Federal deverá julgar brevemente duas Ações Diretas de Inconstitucionalidade (ADINs) sobre o Ensino Religioso na Escola Pública: a ADIN 4439, focada na questão do Acordo Brasil-Vaticano, já aprovado pelo Congresso (que tem força constitucional) e outra, contra a Lei 3.459/2000 do Estado do Rio de Janeiro através da ADIN 3268 que, na prática, instituiu o Ensino Religioso confessional nas escolas públicas desse estado. Mas cabe ao Supremo julgar a inconstitucionalidade das leis, interpretar a Constituição, nunca revogar um dispositivo da Constituição. Seja qual for a decisão do STF, a previsão constitucional do Ensino Religioso será mantida, a não ser que ela seja revogada por emenda do Congresso nacional, o que, no momento, está fora de 
cogitação. Mas o STF pode julgar o Ensino Religioso na escola pública como constitucional e estabelecer aditivos, ou seja, normas e limites para o seu funcionamento. Diante da evidente omissão legislativa do Congresso Nacional frente a várias questões de grande importância para a sociedade brasileira, estamos em plena fase da judicialização da política e, na prática, do Supremo têm exarado decisões judiciais que são verdadeiras normas de lei, em julgamentos de grande repercussão nacional.

Vê-se que se trata de uma questão política relevante e que traz várias outras implicações para a sociedade brasileira. Mas a questão fundamental é: há necessidade do Ensino Religioso na escola pública? Este artigo pretendeu, na verdade, iniciar uma discussão que busque dar uma resposta, ainda que parcial e provisória, a esta questão. Entendemos que um projeto de Ensino Religioso que busque realizar a aplicação da(s) Ciência(s) da Religião para a escola pública, como pretende o Sistema Estadual de Ensino do Paraná, poderá ter grande relevância para a educação. Ao finalizar este trabalho, podemos ressaltar algumas preocupações e alguns questionamentos que permanecem e nos obrigam a colocar o Ensino Religioso na escola pública na agenda da sociedade.

O Ensino Religioso contribui ou não para a formação do ser humano complexo e completo? Sabemos que a religiosidade faz parte intrínseca da humanidade e que a educação parte do humano como razão fundante, se insere permanentemente em suas estratégias e a ele se destina em todos os seus objetivos. Por isso, há necessidade de tornar mais clara a relação entre a educação e as religiões e indagar que papel poderá exercer o Ensino Religioso na formação dos educandos ao lado das demais disciplinas da escola.

O Ensino Religioso contribui ou não para a convivência social? Sabemos que a escola prepara a pessoa para o convívio social, e a cidadania que a escola busca formar inclui informações teórico-metodológicas, sensibilização artística, formação política e preparação para a vida em sociedade. O Ensino Religioso poderá contribuir com a formação da cidadania nesses diversos aspectos?

As tradições religiosas são portadoras de éticas que orientam e disciplinam a vida de seus adeptos na convivência interna do grupo e na vida social. Então, podemos também indagar: o Ensino Religioso poderá contribuir na explicitação de consensos éticos a partir das tradições religiosas?

No dizer de Paulo Freire, a leitura de textos e a leitura da realidade devem ser simultâneas para que, de fato, formem o cidadão crítico e autônomo. Assim como se educam os olhares racional, estético e ético nas diversas disciplinas, o olhar simbólico sobre a realidade pode receber também receber um aporte do Ensino Religioso? 
Por fim, o Ensino Religioso pode ser visto como integração do conhecimento, já que os estudos atuais de epistemologia têm ressaltado a fragmentação das ciências em suas diversas áreas, de forma a perder a sua visão de conjunto. Os currículos escolares refletem também esta fragmentação. A construção de currículos transdisciplinares é desejável, mas ainda está longe de ser alcançada. O Ensino Religioso tem condições de contribuir com a necessária integração dos conhecimentos pela sua natureza e objetivos? Ele tem condições de contribuir para a superação desta fragmentação do conhecimento, da desumanização da ciência e da construção de uma ética para todos os campos de conhecimento?

Todos estes pontos sobre o Ensino Religioso são pautas da educação geral do cidadão. A educação laica para a cidadania não pode ignorar as religiões, pela sua forte presença e função social. É preciso decodificar criticamente as representações e práticas religiosas em nome da convivência sempre mais construtiva entre as pessoas e grupos, educar para a convivência social das diversidades confessionais, assim como tirar das tradições religiosas valores que contribuam com a vida humana na sua subsistência e convivência.

\section{REFERÊNCIAS}

DA COSTA, Néstor (Org.). Laicidad en América Latina y Europa, repensando lo religioso entre lo público y lo privado en el siglo XXI. Uruguay: Instituto Universitario CLAEH -Red Puertas, 2006.

BOURDIEU, Pierre. Descrever e prescrever: as condições de possibilidade e os limites da eficácia política. In: A economia das trocas linguísticas. Tradução de Sérgio Micelli. São Paulo: Edusp, 1996.

FISCHMANN, Roseli (Org.). Ensino Religioso em Escolas Públicas. São Paulo: Factash Editora, 2008.

FONAPER, Parâmetros Curriculares Nacionais, Ensino Religioso. São Paulo: Ave Maria, 1997.

GIRARD, René. A violência e o sagrado. São Paulo: Paz e Terra-UNESP, 1990.

HERVIEU-LÉGER, Daniéle. O Peregrino e o Convertido: a religião em movimento. Petrópolis: Vozes, 2008.

MIELKI, Ana Claudia. O poder das palavras: descrever e preservar. In: Revista Rumores. 6. ed., vol. 1, set-dez/2009. São Paulo: MediAto (Grupo de Estudos de Linguagem e Práticas Midiáticas (ECA-USP). Disponível em

<http://www.usp.br/rumores/>. Acesso em: 19 jul. 2012.

MIGNOLO, Walter. Histórias locais/projetos globais: colonialidade, saberes subalternos e pensamento liminar. Belo Horizonte: Editora UFMG, 2003. 
MORIN, Edgar. A cabeça bem-feita: repensar a reforma, reformar o pensamento. Rio de Janeiro: Bertrand Brasil, 2000.

PONDÉ, L. F. Em busca de uma cultura epistemológica. In: TEIXEIRA, F. L. C. (Org.). A(s) Ciência(s) da Religião no Brasil: afirmação de uma área acadêmica. São Paulo: Paulinas, 2001, p. 11-66.

RIEGER, Jorg. Libertando o discurso sobre Deus. Estudos de Religião, Ano XXII, n. 34, p. 84-104, jan/jun. 2008. São Bernardo do Campo: Editora Metodista, 2008.

STRECK, Danilo R. Uma educação ecumênica: oito proposições sobre um tema controvertido. Estudos de Religião, n. 14, p. 34-48. São Bernardo do Campo: Editora Metodista, 1998.

SENA, Luzia (Org.). Ensino Religioso e Formação docente: ciência da religião e ensino religioso em diálogo. São Paulo: Paulinas, 2006.

SUNG, Jung Mo. Conhecimento e Solidariedade. São Paulo: Salesiana, 2002.

Educar para reencantar a vida. Petrópolis: Vozes, 2006.

TEIXEIRA, Faustino (Org.). A(s) Ciência(s) da Religião no Brasil: afirmação de uma área acadêmica. São Paulo: Paulinas, 2001.

Ciências da Religião e "ensino do religioso". In: SENA, Luzia (Org.). Ensino Religioso e Formação docente: ciência da religião e ensino religioso em diálogo. São Paulo: Paulinas, 2006.

USARSKI, Frank. O Espectro disciplinar da Ciência da Religião. São Paulo: Paulinas, 2008.

Ciência da Religião: uma disciplina referencial. In: SENA, Luzia (Org.).

Ensino Religioso e Formação docente: ciência da religião e ensino religioso em diálogo. São Paulo: Paulinas, 2006.

VELASCO, Demetrio. La construcción histórico-ideológica de la laicidad. In: DA COSTA, Néstor (Org.). Laicidad en América Latina y Europa, repensando lo religioso entre lo público y lo privado en el siglo XXI. Uruguay: Instituto Universitario CLAEH -Red Puertas, 2006, p. 14-31. 